\title{
INOCENTUL ALIENAT ȘI DEPĂȘIREA LIMITELOR (AUTO)IMPUSE
}

\section{Gabriela-Emilia Merce Universitatea de Vest din Timișoara}

Abstract: The starting point of my work is represented by three of Lucian Blaga's plays: Daria, Ivanca and Înviere. We tried to show that the characters of these plays represent pieces of individuality and also these characters will be free from their existential drama only if they will become a mirror for the each other, only if they will be interconnected and if these characters will be able to transfer a part of their identity to another individual.

Key-words: alienation, existential drama, limits, The Character, natural order

\section{Introducere}

Primele receptări ale dramaturgiei blagiene de către critica românească au demonstrat rigiditate în abordarea hermeneutică. Rezerva exegeților exprimată nevădit în ceea ce privește analiza teatrului lui Blaga a fost cauzată tocmai de ceea ce reprezintă în definitiv dramaturgia acestuia. Se poate constata aşadar încă de la primele piese publicate că teatrul lui Blaga impune o viziune nouă: scopul noului teatru nu mai este acela de a caracteriza, ci este acela de a sugera idei-forțe. Astfel, „În dramaturgia de după 1900, subliniază Blaga, se simte o schimbare majoră, cu o mare diversitate de manifestări reductibile însă la câteva tendințe generale: spiritualizarea, esențializarea, conflictele de idei-forțe, dialogizarea problematicii vieții moderne" . De aceea, „dramaturgia blagiană a șocat prin aria problematicii, prin structura neobișnuită a intrigii și a conflictului, prin polisemia și polifonia discursului, prin bogăția imaginilor și autonomia față de mimesisul realist, prin dinamica specială a acțiunii și factura aparte a personajelor"2.

Dramaturgia lui Blaga ilustrează o ancorare la noile orientări privind teatrul, motiv pentru care „Ceea ce încearcă teatrul poetic de idei, ceea ce încearcă, implicit, dramaturgia blagiană, este tocmai întoarcerea dramaticității la originar, la forța cuvîntului resimțită ca energie sacră și la situațiile-sumă, ce racordează umanul dimensiunilor sale esențiale.”3 .

Totodată, „Teatrul nou «nu mai caracterizează», el «creează personajele dincolo de liniile firești», interesul trecând astfel «de la detaliu la esențial, de la concret la abstract, de la imediat la transcendent, de la dat la

\footnotetext{
${ }^{1}$ Doina Modola, Lucian Blaga și teatrul: Insurgentul: memorii, publicistică, eseuri, ediția a doua, București, Editura Anima, 2018, p. 214.

${ }^{2}$ Doina Modola, Lucian Blaga și teatrul: riscurile avangardei, ediția a doua, București, Editura Anima, 2017, p. 15.

${ }^{3}$ Dan C. Mihăilescu, Dramaturgia lui Lucian Blaga, Cluj-Napoca, Editura Dacia, 1984, p. 15.
} 
problemă»».", de unde rezultă și ceea ce vom încerca să demonstrăm pe parcursul acestei lucrări: la Blaga, apare o contaminare la nivelul comportamental al personajelor care acționează ca niște vase comunicante.

În lucrarea de față, vom ilustra faptul că în urma procesului de contaminare, ,personajele acestui «teatru nou» apar în acțiuni «fără vreo însemnătate anecdotică» dar «culminând în idei-forțe». Într-o atare situație, «personajele nu mai există prin ele însele ca indivizi, ci numai ca exponenți ai unor puteri impersonale angajate în ciocniri care macină sau care salvează». E un context în care personajele "se configurează contrapunctic și sunt împinse spre fapte de demonia energiilor dezlănţuite»" ${ }^{\prime \prime}$, dând naştere Personajului blagian.

\section{Inocentul alienat față în față cu alteritatea}

Pornind de la ideea potrivit căreia personajele blagiene exprimă înainte de toate idei, iar prin felul în care sunt construite observându-se preferința dramaturgului pentru arhetipal, categorial sau pentru relevarea zonelor obscure ale individului, vom constata că în urma acestei contaminări reciproce este relevat insolitul și are loc o eliberare a inconștientului prin ceea ce Blaga numea în - Trilogia culturii - personanță, „o însușire, grație căreia inconștientul răzbate cu structurile, cu undele și cu conținuturile sale până sub bolțile conştiinței." ". Astfel, analizând trei din cele zece piese ale lui Blaga, şi anume Daria, Ivanca şi Inviere, vom surprinde ceea ce determină ca personajele blagiene să acționeze ca niște vase comunicante, transferându-și, astfel, reciproc atitudini și comportamente, generând în acest fel ipostaza Personajului blagian.

Analizând modul în care sunt construite cele trei texte, observăm dintru început că în momentul $t_{0}$, al intrării personajelor principale în scenă, acestea se comportă ca niște străini în propria viață. De aici, deducem că în Daria, Ivanca şi Înviere conflictul nu este susținut doar de disputa conştientinconștient, ci și de faptul că în debutul fiecărei piese personajele reflectă o ruptură de sine, de lume, de ceilalți. În acest context, personajul primește voluntar masca alienatului. Din acest punct de vedere, vom considera că personajele blagiene din momentul $\mathrm{t}_{0}$ se află în ipostaza inocentului alienat. Inocentul alienat se va confrunta cu inadaptarea - ,o încercare de apărare și de protest împotriva unei lumi ce-l face să resimtă, în mod tragic, lipsa echilibrului și armonia pierdută, precum și condiţia sa de înstrăinare, o modalitate specifică a omului de a reflecta subiectiv distrugerea echilibrului

\footnotetext{
${ }^{4}$ Constantin Cubleșan, Lucian Blaga: zece ipostaze teatrale, Cluj-Napoca, Editura Dacia XXI, 2011, p. 6.

${ }^{5}$ Idem, ibidem.

${ }^{6}$ Lucian Blaga, Trilogia culturii, București, Humanitas, 2011, p. 46-47.
} 
dintre el şi societate.”

Alienarea va impune așadar detașarea în momentul $t_{0}$, care trebuie privită ca o evadare a personajului din datele sinelui. Este ceea ce Harold Bloom definește - în studiul său despre alienare, inclus în colecția Bloom's Literatury Themes - ca teamă existențială atunci când analizează cazul Kafka. Raportându-ne la Daria din piesa cu același nume, aceasta intră în scenă prin intermediul descrierii realizate de Zugravul: „Doamna e o ființă foarte ciudată. Zece ani am avut prilejul s-o observ de aproape, zilnic. Ei, credeți-mă, o singură dată n-am văzut-o ieșind singură, nici până în pragul ușii [...] Pe femeia asta n-am auzit-o niciodată rîzînd pînă acum cîteva zile aici...”" (Daria, p. 147), de unde reiese că personajul feminin este privat de orice încercare de devenire, dezvoltând o relație alienantă cu ceilalți, întrucât „O relație alienantă este o relație deficitară pe care cineva o are cu sinele, cu lumea, cu ceilalți. Indiferență, instrumentalizare, reificare, absurditate, artificialitate, izolare, neînsemnătate, impotenţă - toate aceste mijloace de caracterizare ale relației în cauză sunt forme la ale acestei deficiențe. $\mathrm{O}$ caracteristică diferită a alienării este cea care nu se referă doar la lipsa de putere și privare de libertate, ci şi la o sărăcire proprie în relație cu sinele și cu lumea." ${ }^{\prime}$.

Observăm aşadar că Daria manifestă o atitudine de retragere din tot ceea ce ar implica interacțiunea. Însă abandonarea sinelui și a lumii nu este una definitivă. Daria renunță la masca inocentului alienat atunci când identifică personajul care să preia funcția de oglindă a interiorităţii ei. În cazul Dariei scriitorul Loga este cel care declanșează revenirea ei în lume, precum şi eliberarea resorturilor interioare, fapt pe care-1 conștientizează și Daria: „T,i-am citit romanul - toată noaptea, cu răsuflarea tăiată. Pe alocuri prezinți copilăria într-o lumină cu totul nouă. E ceea ce m-a izbit mai mult. Dar ai dreptate, copilăria nu e frumoasă. $\mathrm{O}$ știu din proprie experiență. Copilăria mi-o simt încă și azi în toată oribila ei cruzime și suferință [...] Și tristețea continuă până în ziua de azi. $O$, dacă ai ști. Zilele acestea m-ai văzut tot veselă, nu-i așa? Şiacum te miri. Nu sunt aşa cum m-ai văzut. Mă ierți pentru toate destăinuirile ce ți le fac, dar simt - că ție trebuie să-ți spun fără ocolire totul, fiindcă şi aşa îmi știi toate gândurile [...] Alaltăieri te-ai apropiat de mine mai mult [...] Ce puțin

\footnotetext{
${ }^{7}$ Alfred Heinrich, Peregrinările căutătorului de ideal. Inadaptare și alienare în literatură, Timișoara, Editura Facla, 1984, p. 19.

${ }^{8}$ Toate citatele din dramaturgia blagiană vor fi preluate din Lucian Blaga, Opere 3, ediție critică și studiu introductiv de George Gană, București, Editura Minerva, 1986.

${ }^{9}$ Rahel Jaeggi, Alienation, translated by Frederick Neuhouser and Alan E. Smith, edited by Frederick Neuhouser, New York, Colombia University Press, 2014, p. 5-6; „An alienated relation is a deficient relation one has to oneself, to the world, and to others. Indifference, instrumentalization, reification, absurdity, artificiality, isolation, meaninglessness, impotence-all these ways of characterizing the relations in question are forms of this deficiency. A distinctive feature of the concept of alienation is that it refers not only to powerlessness and a lack of freedom but also to a characteristic impoverishment of the relation to self and world." (traducerea mea).
}

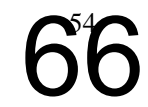


mi-a trebuit să uit tot trecutul! Ce puțin mi-a trebuit să mă înnoiesc! În aceste șapte zile [...] am răsturnat și am reclădit - nu numai aici - ci și înăuntru." (Daria, p. 153). Din confesiunea Dariei deducem că aceasta depășeste pragul unei relații alienante în accepțiunea lui Rahel Jaeggi și, mai mult decât atât, Daria începe să se accepte.

Atracția pe care o dezvoltă pentru Loga este dublată de dezlănțuirea energiilor sale primare. În acest context, pulsiunile interioare vor ordona acțiunea întregii drame, întrucât „Conflictul va urmări cu precădere acele zone ale umanului ce păstrează tiparul primordial, personajele vor fi încărcate cu energie esențială, daimonică, situațiile vor gravita mai întotdeauna în jurul Limitei [...], soluțiile vor fi, aproape fără excepție, soluții finale, de desăvîrșire a trăirii și de consumare plenară a Eului sau a Ideii, rostirea va căpăta ritmuri profunde, tragice, accente rituale. $" 10$.

În Ivanca, inocentul alienat este Luca. La fel ca în cazul Dariei și acesta este introdus în scenă prin descrierile făcute de alte personaje. Dialogul dintre Tatăl şi Dinu din debutul dramei surprinde, ca în cazul Dariei, o ruptură a personajului de lume, de ceilalți. De această dată relația alienantă cu sinele, cu lumea, cu ceilalți, este redată nu prin izolare sau impotența evadării ca în Daria, ci prin manifestarea unei indiferențe de afirmare.

Considerând că ,înstrăinarea este o formă aparte a relației, nu o nonrelație sau nici măcar o absență a relației. Înstrăinarea descrie nu absența relației, ci calitatea acesteia. Chiar dacă pare paradoxal, întrăinarea e o relație a nerelaționării" "11 , este de înțeles atitudinea lui Luca în ceea ce privește legătura cu alteritatea. Replica Tatălui - „Se adună în colț, uite colo, nemișcat ca o piatră. S-ar zice că ține judecată asupra oamenilor. De multe ori stă toată ziua întreagă așa. Nu și-ar mișca un deget. Cînd se uită în jur, parcă se miră că e încă tot pe pămînt.” (Ivanca, p. 244) - dublată de cea a lui Dinu - „Gândul de care-1 vezi abătut e mai greu decît orice boală." (Ivanca, p. 244) - indică ascunderea personajului sub masca inocentului alienat, care într-un joc ulterior al măștilor scenice susținut de prezența Ivancăi va intra într-un proces al contaminării reciproce. Astfel, „Ivanca valorizează resorturile opționale ezitante ale pictorului, ea prilejuind, prin absorția Paternului, ruperea lui Luca din marasmul stirpei marcate., $"$.

De aceea, ,Nu numai că personajele axiale din teatrul blagian AU, în ciuda «stilizării», lor în numele tezei, o psihologie pregnantă și complicată, dar ei sînt în majoritate niște personaje accentuate, cu ezitări fundamentale și cu opțiuni vitale, cu trăiri exacerbate, motivate întotdeauna fie de logica

\footnotetext{
${ }^{10}$ Dan C. Mihăilescu, op. cit., p. 15.

${ }^{11}$ Rahel Jaeggi,op. cit., p. 25; ,alienation is a specific form of relation, not a nonrelation or the mere absence of a relation. Alienation describes not the absence but the quality of a relation. Formulated paradoxically, alienation is a relation of relationlessness.", traducerea mea.

${ }^{12}$ Dan C. Mihăilescu, op. cit., p. 100.
} 
succesiunii evenimentelor, fie de propria lor structură, care-i condamnă aproape de la sine."13. Așadar, personajele blagiene vor acționa ca niște vase comunicante în măsura în care acestea sunt frânturi dintr-o psihologie colectivă care permite în definitiv crearea Personajului blagian.

De asemenea, personajele axiale capătă contururi din ce în ce mai pregnante odată cu intrarea acestora în procesul de contaminare reciprocă la nivelul trăirilor. În acest sens, personajele secundare răspund ezitărilor existenţiale pe care le exprimă personajul axial, acestea devenind forțe ordonatoare pentru o existență lipsită de sens. Din acest punct de vedere, personajele blagiene reprezintă mai degrabă idei-forțe și nu indivizi, întrucât în teatrul lui Blaga nu primează nevoia de organizare a socialului, ci aceea de dezvăluire a originarului, a primarului. Astfel, „Psihologicul înseamnă, în teatrul lui Blaga, întîi de toate adecvarea personajului la ideea pe care o reprezintă și abia apoi la contextul situaţional în care evoluează. Or «stilizarea» comportamentelor nu face decît să concentreze atenția pe ceea dintîi adecvare, tocmai spre a modifica cît mai convingător procesul imediat următor: adecvarea sau nonadecvarea la situația dramatică."14.

În Inviere, figura inocentului alienat se definește ulterior momentului $\mathrm{t}_{0}$. În această piesă, accentul cade pe relevarea ancestralului prin intermediul refacerii unei lumi în care naturalul domină umanul. În acest context, personajele blagiene devin simple instrumente de redare a unei ordini primare. De aceea, în pantomima Înviere sunt mai importante procesele decât faptele. Astfel, ipostaza inocentului alienat este înlocuită de înstrăinarea ca proces. În Inviere, înstrăinarea marchează ruptura de ordinea firească și crearea unei lumi „pe dos”, lumea viilor devenind comună lumii morților, lumea ca centru devenind lumea ca margine. Toate aceste modificări sunt cauzate de prelungirea nesfârșită a unui moment $\mathrm{t}_{0}$ al înstrăinării.

Observăm așadar că „Blaga recomandă înnoirea pe diverse paliere a structurii: metaforă spiritualistă, psihanalitică şi categorială, univers al personajelor (iluminați, mari păcătoși și mari convertiți), tipuri de eroi (ideiforțe, personaje generice, arhetipuri, ipostazieri ale personalității, proiecții subliminale, personaje istorice).,"

\section{Cazul Daria și Ivanca: reprezentări ale falsei dominări de sine}

Depăşirea acelui moment $\mathrm{t}_{0}$, al înstrăinării, reprezintă totodată cauza dezvoltării unui conflict între conștient și inconștient, care se soluţionează prin acceptarea datelor aduse de inconștient conștientului. În acest conglomerat de forțe, ceea ce putem constata dintru început e că personajele blagiene își impun

\footnotetext{
${ }^{13}$ Idem, ibidem, p. 73.

${ }^{14}$ Idem, ibidem, p. 72.

${ }^{15}$ Doina Modola, Lucian Blaga şi teatrul: Insurgentul: memorii, publicistică, eseuri, ed. cit., p. 215.
} 
sau acceptă cel mai adesea cenzura, dar care în definitiv se dovedește a fi o falsă reprezentare de dominare a sinelui. Recurgând la cenzură, personajele blagiene nu fac altceva decât să contribuie la agonia sinelui, care odată eliberat va da naștere unor soluții finale. Lucian Blaga subliniază în Trilogia culturii că „Efectele personanței, unele permanente, altele instantanee, sunt incalculabile. De o parte inconștientul colorează și nuanțează necurmat conștiința, de altă parte inconștientul izbutește uneori să se constituie, în întruchipări de sine stătătoare, chiar în spațiul propriu al conștiinței."16. Blaga fundamentează așadar la nivel teoretic ceea ce experimentează la nivelul discursului dramatic. În acest context, Daria și Ivanca sunt mostre care sprijină demersul teoreticofilosofic al acestuia, ilustrând că „Fără de personanțele inconștientului, viața conștientă ar câștiga probabil ca precizie și luciditate, dar ar pierde ca plasticitate. Inconștientul împrumută conștiinței infinite nuanțe, vagul, neliniștea, contradicții de stratificare, obscurități și penumbre, adică perspectivă, caracter și un profil multidimensional." ${ }^{\prime \prime}$.

Raportându-ne la Daria și Ivanca, observăm că adoptarea unei atitudini de respingere a oricărei forme a alterității determină personajele blagiene să-și (auto)impună limite existențiale. Limitarea existențială se manifestă prin cenzura manifestărilor comportamentale, prin crearea unui blocaj la nivel senzorial și cognitiv. Personajele axiale din cele două drame, Daria și Luca, se depărtează de alteritatea pe care o percepe ca fiindu-le străină, permițându-se în termenii utilizați de Alfred Heinrich „o automutilare a inadaptatului”, întrucât „Fuga de realitate înseamnă tot mai mult scăparea de absurd. Posibilitățile sunt infime, fiindcă inadaptatul folosește în încercarea lui disperată un întreg aparataj al absurdului, evadînd în spaţii anormale sau fantastice." ${ }^{18}$. În cazul celor două personaje blagiene, nu are loc nicio evadare în spații anormale sau fantastice, ci, dimpotrivă, are loc o eliberare a inadaptatului prin renunțarea la cenzură, la dominarea excesivă a instinctualității.

Identificarea unor reprezentări ale falsei dominări de sine este posibilă datorită personajelor blagiene care acționează ca niște vase comunicante. Prin faptul că acestea se provoacă reciproc și își impun limitări, are loc un transfer continuu de comportamente. În acest context, personajele își pierd autonomia şi devin măști scenice doar în momentul în care fac parte dintr-un sistem de personaje. Vom observa că atât Daria, cât și Luca vor suporta simultan cenzura impusă de celălalt, precum și o autocenzură.

Referitor la Daria, aceasta nu reușește nici măcar pentru un moment să fie stăpână pe sine. Ea se definește întotdeauna prin raportare la celălalt. Daria se închide în sine sau dimpotrivă își eliberează resorturile interioare doar

\footnotetext{
${ }^{16}$ Lucian Blaga, Trilogia culturii, București, ed. cit., p. 47.

${ }^{17}$ Idem, ibidem .

${ }^{18}$ Alfred Heinrich, op. cit., p. 156.
} 
în relație cu alteritatea. „Pentru Filip, Daria este persoana cu grave tulburări mentale, în pragul nebuniei, care trebuie tratată prin sechestrare și singurătate" ${ }^{19}$, percepție pe care o adoptă inițial, fără rezerve, și Daria, întrucât aceasta mărturisește că „În sîngele meu mocnesc catastrofe. Lucru de necrezut, dar adevărat, aşa cum mă vezi: sunt sufletește bolnavă... Și, ce e mai grav, miam acceptat boala ca o soartă, stau în fața ei cu priviri fără protest. Nu-mi pot ajuta ajuta cu nimic, nu mai cred decît într-un remediu miraculos" (Daria, p. 160). Totuși, „drama izolării sufleteşti a femeii nu poate avea nici un ecou în conştiinţa bărbatului obsedat de - şi limitat la - arestarea personalităţii umane într-o cuşcă determinată încă din faza embrionară."20.

Însă pentru Loga, vindecarea Dariei nu constă în izolarea acesteia de lume, ci, dimpotrivă, e nevoie de includerea personajului feminin în ritmul devenirii lumii. Astfel, prin faptul că personajele blagiene se influențează reciproc, Daria resimte apropierea de Loga ca o renaștere, deoarece „,simt această bucurie a eliberării. Da, recunosc, trebuie să vorbesc. Numai aşa uit definitiv. Tu nu știi cum e asta - îmi vine să mă duc și între ființe necuvîntătoare, între dobitoace și pomi - să le spun: sunt liberă! Între pomi, între pietre, între ape - să strig: sunt sănătoasă şi limpede!" (Daria, p. 168). Dar, bucuria eliberării pe care o verbalizează exponentul feminin se va dovedi a fi un fals simptom al redobândirii de sine, întrucât Filip va împiedica revelarea resorturilor interioare ale Dariei prin impunerea unei soluții finale: privarea comunicării cu Loga - o imagine a interiorității acesteia - dublată de închiderea într-un spațiu steril, care accelerează, fără îndoială, degradarea Dariei, iar in extenso provoacă gestul final al lui Puiu. De aceea, replica lui Filip „Nu uita că libertatea ta e în buzunarul meu!” (Daria, p. 195) devine hotărâtoare în tot acest proces relevării-sublimării sinelui.

În ceea ce-1 privește pe Luca, Doina Modola afirmă că „Necontenita reprimare a instinctului îi dă lui Luca un stăruitor sentiment de deznădejde şi anxietate din care se eliberează fantasmele."21, întrucât personajul axial dỉn Ivanca încearcă neîncetat să-și cenzureze existența. Pe de o parte, refuză comunicarea cu lumea cu scopul de a-și domina pornirile interioare, fapt ce reiese din replica lui Dinu: „E cel puțin la fel de normal ca și noi. Că e tăcut ce are a face? Că îl prigonește un gînd? Pornirile lui - de care se teme! De! Poate că sunt mai generale și mai normale decît ne place să credem. Eu le am, dumneata le ai, toți le avem. Şi, ca și noi și toți ceilalți, s-a închis şi el de bunăvoie într-o cușcă. De teama de sine. La fel facem toți. Închiși în cuști

\footnotetext{
${ }^{19}$ Constantin Cubleșan, (coord.), Dicționarul personajelor din teatrul lui Lucian Blaga, ClujNapoca, Editura Dacia, 2005, p. 111.

${ }^{20}$ Lucian Bâgiu, Lucian Blaga și teatrul. Eseu despre absolutul estetic, Colecția OPERA OMNIA publicistică și eseu contemporan, Iași, Editura Tipo Moldova, 2014, p. 76.

${ }^{21}$ Doina Modola, Lucian Blaga și teatrul: jocurile dramei:Tulburarea apelor, Fapta, Daria, Inviere, București, Editura Anima, 2017, p. 194.
} 
ambulante umblăm pe străzi, în societate, și pretutindeni, și rînjim fericiți ca zeii intermundii. Ecce homo." (Ivanca, p. 249). Pe de altă parte, își proiectează o lume proprie prin vis și prin pictură, cele două devenind instrumente de eliberare a inconștientului, deci de eliberare nevoită a sinelui. Astfel, „Luca proiectează în vis reprezentările diurne și veșnicul eșec al dominării de sine." ${ }^{, 2}$.

Totodată, Luca, spre deosebire de Daria care identifică imediat în Loga proiecția interiorității sale, ezită contactul cu Ivanca, întrucât personajul masculin simte imanentul. Cel dintâi dialog dintre Luca și Ivanca surprinde aşadar hotărârea personajului feminin de a se impune ca forță eliberatoare a instinctualității lui Luca, precum și cea a pesonajului masculin de a se opune relevării părții sale absconse: „Luca: De unde vii? Parcă din noaptea mea lăuntrică te-ai ridicat. Oh, de ce-ai venit? De ce-ai venit? Eu cred că nenorocirea cu tine va începe./ Ivanca: Nu mă alunga. Încă nimenea nu m-a trimis înapoi. Bucură-te şi primește-mă.” (Ivanca, p. 262). De altfel, limita existenţială pe care și-a impus-o Luca îl sufocă. Deși conștientizează că dominarea sinelui nu este o soluție definitivă, totuși Luca găsește în această acțiune posibilitatea amânării inevitabilului pe care o justifică astfel: „Ce să-ți pun? Poți tu să înțelegi? Acesta-i începutul. Trebuie să ocolesc inevitabilul faptei. Ascultă. Închide ochii și ascultă. Unde mai pot să fug? Unde mă ascund? Ceva grozav are să se întâmple." (Ivanca, p. 260). Însă, nu doar Ivanca are rol în procesul dezvăluirii instinctualității lui Luca, ci și Tatăl. De aceea, „Jocul dramatic are ca repere umane trei frânturi de individualitate: pictorul Luca, Tatăl, Ivanca [...]. Ipostaze ale unui întreg al fiinţei, cele trei fragmente au rolul de a configura un puzzle. Fondul este reprezentat de Tatăl şi Ivanca, nuanţe ale gamei absconse care defineşte personalitatea umană al cărei strat vizibil, exterior şi fals se vrea a fi pictorul Luca." ${ }^{23}$. Din acest motiv, Luca prin felul în care este construit este o reprezentare a falsei dominări de sine, astfel încât soluția finală va rămâne doar o ipoteză.

\section{Înviere: despre conștiința oarbă în fața ordinii încălcate}

Relevarea arhetipalului are loc la Blaga din mai multe puncte de vedere. Pe de o parte, redarea Personajului blagian trimite la arhetipal, categorial, iar pe de altă parte, preferința dramaturgului pentru subiectele mari devine o condiție pentru exprimarea ideii de arhetip. „In viziunea lui Blaga, există un substrat al lumii, dificil de perceput sau de exprimat, dar prezent atât în natură, în universul exterior ilimitat, cât şi în om, în inconştientul colectiv al omenirii [...]. Prin intermediul acestui fond ascuns în fiinţă şi vag întrezărit în manifestările sale, omul are şansa de a se integra absolutului cosmic." ${ }^{24}$. Din

\footnotetext{
${ }^{22}$ Idem, ibidem, p. 193.

${ }^{23}$ Lucian Bâgiu, op. cit., p. 86.

${ }^{24}$ Idem, ibidem., p. 66.
} 
acest punct de vedere, pantomima Înviere reflectă acțiunile omului întreprinse cu scopul reintegrării sale într-o ordine naturală. „Pantomima lui Lucian Blaga se așează (sic!) astfel în viziunea dramaturgului, într-un ceremonial ce cuprinde într-un semn catalizator și începutul lumii." 25 , întrucât lumea descrisă în acest text dramatic reface momentul genezei prin faptul că încălcarea ordinii naturale atrage sancțiuni ireversibile.

Prezentarea destinului Voichiței este elementul centralizator al întregii drame existențiale din Inviere. Voichița este de fapt o proiecție in extenso a personajului feminin, Mama. De aceea, căsătoria Voichiței nu determină doar înstrăinarea de singurul loc în care devenirea sa era înscrisă în ritmul tacit al naturii, ci şi îndepărtarea de Mama - imagine a interiorității ei. Totodată, în Inviere se produce o resurecție a vechii ordini naturale, care se va impune ca forță totalizatoare. În acest context, amestecul lumilor este premergător actului restaurării echilibrului natural, motiv pentru care ,întâlnim spiritele unei lumi fantastice, magice, venită de dincolo de orizonturile imediate." 26 , iar personajele pantomimei devin exponenți ai unor forțe primare, originare. De aceea, Mama prinsă între lumi se sacrifică pentru ca ordinea încălcată prin înstrăinarea propriei fete să fie restabilită. Mama se impune astfel ca forță tutelară peste lumea morților și peste cea a viilor, apropiindu-le pe cele două până la nediferențiat. Vom oberva că doar revenirea Voichiței permite separarea celor două lumi, susținută și de intrarea Mamei în lumea de dincolo. Așadar, mânată de conștiința oarbă, Mama restabilește vechea ordine prin desăvârșirea Voichiței ca centru existențial al comunităţii în care a fost reintegrată.

\section{Concluzii}

Prin urmare, personajele blagiene, construite ca niște vase comunicante, furnizează întotdeauna idei-forțe. Mai mult decât atât, acestea permit redarea Personajului blagian, care însumează totalitatea măştilor scenice. Personajul blagian este proiectat supradimensional, acesta devenind parte din fondul ascuns pe care dramaturgul încearcă să-l reveleze. Din acest punct de vedere, sacrificarea individualității personajelor prin dezlănţuirea resorturilor interioare este obligatorie în procesul devenirii Personajului blagian, care, în definitiv, este format din frânturi de individualități ce acționează contrapunctic. Așadar, Personajul blagian este cel care exprimă idei, pe când personajele blagiene ca frânturi de individualitate își pierd autonomia și singularitatea într-un joc frenetic al înstrăinării, al cenzurii și al eliberării de limitele existențiale. De aceea, „sacrificiul se instaurează în traseul dramatic blagian ca măsură, ca desăvîrșire adică, a unei evoluții de sine. Eul dramatic este, la Blaga, emblema unei căutări, este un drum printre cauze

${ }^{25}$ Constantin Cubleșan, Lucian Blaga: zece ipostaze teatrale, ed. cit., p. 102.

${ }^{26}$ Lucian Bâgiu, op. cit., p. 113.

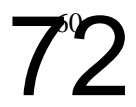


contrare, o sumă de efecte antonimice pe care momentul opțiunii le însumează, dîndu-le, prin decizie, o rezolvare." 27 .

\section{Bibliografie}

Bâgiu, Lucian, Lucian Blaga și teatrul. Eseu despre absolutul estetic, Colecția OPERA OMNIA publicistică și eseu contemporan, Iași, Editura Tipo Moldova, 2014.

Blaga, Lucian, Opere 3, ediție critică și studiu introductiv de George Gană, București, Editura Minerva, 1986.

Blaga, Lucian, Trilogia culturii, București, Humanitas, 2011.

Cubleșan, Constantin (coord.), Dicționarul personajelor din teatrul lui Lucian Blaga, Cluj-Napoca, Editura Dacia, 2005.

Cubleșan, Constantin, Lucian Blaga: zece ipostaze teatrale, Cluj-Napoca, Editura Dacia XXI, 2011.

Heinrich, Alfred, Peregrinările căutătorului de ideal. Inadaptare și alienare $\hat{\imath} n$ literatură, Timișoara, Editura Facla, 1984.

Jaeggi, Rahel, Alienation, translated by Frederick Neuhouser and Alan E. Smith, edited by Frederick Neuhouser, New York, Colombia University Press, 2014.

Mihăilescu, Dan C., Dramaturgia lui Lucian Blaga, Cluj-Napoca, Editura Dacia, 1984.

Modola, Doina, Lucian Blaga și teatrul: Insurgentul: memorii, publicistică, eseuri, editia a doua, București, Editura Anima, 2018.

Modola, Doina, Lucian Blaga și teatrul: jocurile dramei:Tulburarea apelor, Fapta, Daria, Înviere, București, Editura Anima, 2017.

Modola, Doina, Lucian Blaga și teatrul: riscurile avangardei, ediția a doua, București, Editura Anima, 2017.

${ }^{27}$ Dan C. Mihăilescu, op. cit., p. 58. 